Diabetologia 7, 247-251 (1971)

(C) by Springer-Vorlag 1971

\title{
Insulin and Glycosuria
}

\author{
G.S. SPathis \\ The Middlesex Hospital, London, England \\ Received: November 14, 1970, accepted: May 11, 1971
}

Summary. An effect of insulin on glycosuria independent of its effect on blood sugar was demonstrated in a group of seven diabetics. To do this it was necessary to develop a technique in which the hypoglycaemic effect of insulin could be isolated and overcome. This was achieved by monitoring the arterial blood glucose continuously and infusing glucose intravenously as necessary to maintain the arterial concentration. The technique may be useful in other investigations. The significance of the results is discussed. This is the first time that such an effect of insulin has been demonstrated, and it suggests that present theories on the renal handling of glucose are inadequate.

\section{Insuline et glycosurie}

Résumé. Dans un groupe de 7 diabétiques, nous avons démontré un effet de l'insuline sur la glucosurie, qui est indépendant de son effet sur le sucre du sang. Dans ce but il a fallu développer une technique dans laquelle l'effet hypoglycémiant de l'insuline pouvait être isolé et surmonté, cela, en mesurant continuellement le glucose du sang artériel et en infusant, par voie intra-veineuse, une quantité do glucose suffisante pour maintenir la concentration artérielle. La technique peut être utile pour d'autres recherches. La signification des résultats est discutée. C'est la première fois que l'on parvient à démontrer un effet semblable de l'insuline et cela suggère que les théories actuelles sur le comportement du glucose dans les reins sont inexactes.

\section{Insulin und Glykosurie}

Zusammenfassung. An sieben Diabetikern wurde ein Effekt von Insulin auf die Glykosurie unabhängig von seinem Effekt auf den Blutzuck эr nachgewiesen. Dafür war es notwendig, eine Technik zu entwickeln, mit der der hypoglykämische Effekt des Insulins isoliert und überwunden werden konnte. Dieses wurde durch kontinuierliche Messung des arteriellen Blutzuckers und intravenöse Infusionen von so viel Glukose wie notwendig, um die arterielle Konzentration zu halten, erreicht. Diese Technik kann auch bei anderen Untersuchungen von Nutzen sein. Die Bedeutung der Ergebnisse wird diskutiert. Dies ist das erste Mal, daß ein solcher Effekt des Insulins aufgezeigt wurde und man kann vermuten, daß die augenblicklichen Theorien über die Behandlung der Glukose durch die Nieren nicht adäquat ist.

Key-words. Diabetes-insulin-renal effect, glycosuria, continuous glucose monitoring.
The factors influencing the renal handling of glucose are not well defined and the role of insulin is unknown. Dzurik and co-workers [2] suggested that insulin increased the uptake of glucose by the rat kidney; and Henningsen and Benveniste [6] found that tolbutamide had a variable, and statistically insignificant, effect on the renal handling of glucose. We do not know the cause of the varying renal threshold for glucose in normals or diabetics [1], or for the gly cosuria of pregnancy [10], or that following the ingestion of corticosteroids [8]. In all these conditions serum insulin levels may be elevated. Furthermore, patients with 'renal glycosuria' have been found to have a hyperinsulinaemic response to glucose [6]. It therefore seemed worth investigating the effect of insulin on the urinary excretion of glucose.

The usual measure of the renal handling of glucose - the Tubular Maximal Reabsorbtive Capacity involves the infusion of glucose which alters the level of insulin in the blood. A different approach was therefore needed to allow a constant arterial glucose level to be maintained despite the infusion of insulin.

\section{Subjects}

The results in eight subjects are reported. Seven were diabetic, but only two had received previous antidiabetic therapy (Nos. 4 and 5 in Table 1). None had any known renal or cardiovascular disease. Studies on two other patients were unsatisfactory - in one due to inability to pass urine, and in the other, failure to control the blood glucose adequately - and these results are not reported. All the patients had volunteered to take part in the investigation and knew that it was not a necessary part of the treatment of their disease.

\section{Methods}

Blood was sampled continuously through a fine intra-arterial double lumen catheter [11], and the glucose concentration measured on an Autoanalyser using a modification [12] of the Hill and Kessler glucose-oxidase method [7]. Urinary, and on one occasion blood, creatinine was measured on an Autoanalyser (Method N-11a). Glomerular filtration rate was measured in one patient with ${ }^{57} \mathrm{Co}-$ Vitamin $\mathrm{B}_{12}[4]$. 
Table 1. Results in seven diabetic subjects and one non-diabetic

Patients labelled A given loading dose of insulin $(0.1 \mathrm{u} / \mathrm{kg}$ body weight) as well as a continuous infusion (0.1 u/kg/h); those labelled B received only the continuous infusion (same dosage). Patients 4 and 5 had received previous treatment for their diabetes. Patient 5 was given 6 units sol. insulin s.c. six hours before test. Patient 6 is the only female. G.F.R.: in Patient 2 estimated by ${ }^{57} \mathrm{Co}-{ }^{7}$ it. $\mathrm{B}_{12}$, in Patient 6 estimated as endogenous creatinine clearance. 'Tubular re-absorption' in Patient 7 was calculated assuming a constant G.F.R. of $120 \mathrm{ml} / \mathrm{min}$

\begin{tabular}{|c|c|c|c|c|c|c|c|c|c|c|c|c|}
\hline \multirow[b]{2}{*}{ Patient } & \multirow[b]{2}{*}{$\begin{array}{l}\text { Speci- } \\
\text { men** }\end{array}$} & \multirow[b]{2}{*}{$\begin{array}{l}\operatorname{Time} \theta \\
(\min )\end{array}$} & \multirow[b]{2}{*}{$\begin{array}{l}\text { Volume } \\
\text { ml }\end{array}$} & \multirow[b]{2}{*}{$\begin{array}{l}\text { Flow } \\
\text { Rate } \\
\mathrm{ml} / \mathrm{min}\end{array}$} & \multirow{2}{*}{$\begin{array}{l}\text { Glucose } \\
\text { Conen. } \\
\mathrm{mg} / \\
100 \mathrm{ml}\end{array}$} & \multirow[b]{2}{*}{$\begin{array}{l}\text { Excre- } \\
\text { tion } \\
\mathrm{mg} / \mathrm{min}\end{array}$} & \multicolumn{2}{|c|}{ Creatinine } & \multirow[b]{2}{*}{$\begin{array}{l}\mathrm{mg} \\
\text { Glucose } \\
\text { /mg } \\
\text { creat. }\end{array}$} & \multirow[b]{2}{*}{ G.F.R. } & \multirow[b]{2}{*}{$\begin{array}{l}\text { Blood } \\
\text { Glucose } \\
\text { (mean) }\end{array}$} & \multirow[b]{2}{*}{$\begin{array}{l}\text { 'Tubular } \\
\text { Reab-" } \\
\text { sorption' }\end{array}$} \\
\hline & & & & & & & $\begin{array}{l}\text { Concn. } \\
\mathrm{mg} / \\
100 \mathrm{ml}\end{array}$ & $\begin{array}{l}\text { Excre- } \\
\text { tion } \\
\mathrm{mg} / \mathrm{min}\end{array}$ & & & & \\
\hline $1 \mathrm{~A}$ & $\stackrel{\mathrm{C}}{\mathrm{E}}$ & $\begin{array}{l}39 \\
50.5\end{array}$ & $\begin{array}{l}139 \\
295\end{array}$ & $\begin{array}{l}3.56 \\
5.85\end{array}$ & $\begin{array}{l}510 \\
135\end{array}$ & $\begin{array}{r}18.2 \\
7.9\end{array}$ & - & & & & $\begin{array}{l}184 \\
177\end{array}$ & \\
\hline $2 \mathrm{~A}$ & $\begin{array}{l}\mathrm{C} \\
\mathrm{E}\end{array}$ & $\begin{array}{l}43.25 \\
36.5\end{array}$ & $\begin{array}{r}91 \\
432\end{array}$ & $\begin{array}{r}2.1 \\
11.8\end{array}$ & $\begin{array}{r}2075 \\
160\end{array}$ & $\begin{array}{l}43.6 \\
19\end{array}$ & $\begin{array}{c}49 \\
8.5\end{array}$ & $\begin{array}{l}1.03 \\
1.01\end{array}$ & $\begin{array}{l}42.3 \\
18.8\end{array}$ & $\begin{array}{l}112 \\
109\end{array}$ & $\begin{array}{l}209 \\
212\end{array}$ & $\begin{array}{l}190 \\
212\end{array}$ \\
\hline $3 \mathrm{~A}$ & $\begin{array}{l}\mathrm{C} \\
\mathrm{E}\end{array}$ & $\begin{array}{l}35.5 \\
23\end{array}$ & $\begin{array}{l}635 \\
386\end{array}$ & $\begin{array}{l}17.9 \\
16.8\end{array}$ & $\begin{array}{c}49 \\
8.2\end{array}$ & $\begin{array}{l}8.8 \\
1.4\end{array}$ & $\begin{array}{c}18 * \\
7\end{array}$ & $\begin{array}{l}3.22 * \\
1.17\end{array}$ & $\begin{array}{l}2.72 \\
1.17\end{array}$ & & $\begin{array}{l}132 \\
137\end{array}$ & \\
\hline $4 \mathrm{~B}$ & $\begin{array}{l}\mathrm{C} \\
\mathrm{H}\end{array}$ & $\begin{array}{l}39.75 \\
40.25\end{array}$ & $\begin{array}{l}510 \\
340\end{array}$ & $\begin{array}{r}12.8 \\
8.5\end{array}$ & $\begin{array}{l}6.0 \\
2.9\end{array}$ & $\begin{array}{l}0.77 \\
0.24\end{array}$ & $\begin{array}{l}13 \\
12\end{array}$ & $\begin{array}{l}1.67 \\
1.01\end{array}$ & $\begin{array}{l}0.46 \\
0.24\end{array}$ & & $\begin{array}{l}140 \\
144\end{array}$ & \\
\hline $5 \mathrm{~B}$ & $\stackrel{\mathrm{C}}{\mathrm{E}}$ & $\begin{array}{l}60.5 \\
64.5\end{array}$ & $\begin{array}{l}395 \\
730\end{array}$ & $\begin{array}{r}6.5 \\
11.3\end{array}$ & $\begin{array}{l}2780 \\
1020\end{array}$ & $\begin{array}{l}181.5 \\
115.4\end{array}$ & $\begin{array}{l}42 \\
16\end{array}$ & $\begin{array}{l}2.74 \\
1.81\end{array}$ & $\begin{array}{l}66.2 \\
63.75\end{array}$ & & $\begin{array}{l}266 \\
270\end{array}$ & \\
\hline $6 \mathrm{~B}$ & Mean $\stackrel{\mathrm{C}}{\mathrm{C}} \mathrm{C}$ & $\begin{array}{l}10 \\
11 \\
10 \\
31 \\
10 \\
10 \\
10 \\
10 \\
10 \\
50\end{array}$ & $\begin{array}{l}170 \\
145 \\
120 \\
435 \\
145 \\
125 \\
170 \\
145 \\
145 \\
730\end{array}$ & $\begin{array}{l}17 \\
13.2 \\
12 \\
14 \\
14.5 \\
12.5 \\
17.0 \\
14.5 \\
14.5 \\
14.6\end{array}$ & $\begin{array}{l}226 \\
228 \\
212 \\
- \\
192 \\
172 \\
192 \\
208 \\
170 \\
-\end{array}$ & $\begin{array}{l}38.4 \\
30.0 \\
25.4 \\
31.3 \\
27.8 \\
21.5 \\
32.6 \\
30.2 \\
24.6 \\
27.4\end{array}$ & $\begin{array}{l}4.9 \\
5.0 \\
4.9 \\
- \\
4.9 \\
4.6 \\
4.0 \\
4.8 \\
4.8 \\
-\end{array}$ & $\begin{array}{l}0.83 \\
0.66 \\
0.59 \\
0.71 \\
0.71 \\
0.57 \\
0.68 \\
0.70 \\
0.70 \\
0.67\end{array}$ & $\begin{array}{l}46.1 \\
45.6 \\
43.3 \\
45.0 \\
39.2 \\
37.4 \\
48.0 \\
43.3 \\
35.4 \\
40.7\end{array}$ & $\begin{array}{c}118 \\
106 \\
83 \\
102.3 \\
104 \\
84 \\
106 \\
108 \\
108 \\
102\end{array}$ & $\begin{array}{l}240 \\
240 \\
245 \\
242 \\
242 \\
242 \\
245 \\
245 \\
242 \\
244\end{array}$ & 215 \\
\hline $7 \mathrm{~A}$ & Mean $\frac{\mathrm{C}}{\mathrm{E}}$ & $\begin{array}{l}41.5 \\
28.5 \\
16.5 \\
45.0\end{array}$ & $\begin{array}{r}53 \\
265 \\
175 \\
440\end{array}$ & $\begin{array}{c}1.325 \\
9.3 \\
10.6 \\
9.8\end{array}$ & $\begin{array}{c}101 \\
2 \\
1.7 \\
-\quad\end{array}$ & $\begin{array}{l}1.34 \\
0.186 \\
0.180 \\
0.184\end{array}$ & $\begin{array}{l}94 \\
13 \\
12 \\
-\end{array}$ & $\begin{array}{l}1.24 \\
1.31 \\
1.27 \\
1.23\end{array}$ & $\begin{array}{l}1.08 \\
0.15 \\
0.14 \\
0.149\end{array}$ & & $\begin{array}{l}149 \\
163 \\
159 \\
159\end{array}$ & 192 \\
\hline $\begin{array}{l}8 \mathrm{~A} \\
\text { (Non- } \\
\text { Diabetic }\end{array}$ & $\begin{array}{l}\mathrm{C} \\
\mathrm{E}\end{array}$ & $\begin{array}{l}26.5 \\
32.75\end{array}$ & $\begin{array}{r}52.5 \\
549.5\end{array}$ & $\begin{array}{r}1.98 \\
16.70\end{array}$ & $\begin{array}{l}7.9 \\
0.85\end{array}$ & $\begin{array}{l}0.16 \\
0.14\end{array}$ & $\begin{array}{l}72 \\
8.1\end{array}$ & $\begin{array}{l}1.43 \\
1.36\end{array}$ & $\begin{array}{l}0.11 \\
0.105\end{array}$ & & $\begin{array}{l}84.2 \\
84.6\end{array}$ & \\
\hline
\end{tabular}

$*_{\mathrm{C}}-$ control (baseline) urine

E - experimental (post insulin) urine

Urinary glucose was measured with glucose oxidase [7] the urine being frozen until analysis. Inhibiting factors were removed by activated charcoal as described by Fine [3]. The amount of glucose present was estimated by recovery of internal standards, usually in three different concentrations.

\section{Experimental Procedure}

The patients were well hydrated, resting in bed, and had been fasting for at least six hours. The doublelumen cathether was inserted into a brachial artery, and the patients emptied their bladder for the start of the experiment (in patients 1, 2, 3 and 8 between 11.00 a.m. and noon, and in the remainder after 1.00 p.m.). After a timed baseline urine specimen had been obtained a priming dose of insulin (0.1 units per kilogram body weight) was given intravenously to patients in Group A. This was followed by a continuous infusion of insulin, diluted in normal saline, at a rate of 0.1 units per kilogram body weight per hour. (Patients in Group $B$ were not given the priming dose and the insulin was infused diluted in $10 \%$ dextrose). Following insulin a separate intravenous infusion of $10 \%$ dextrose was started, and the rate of infusion adjusted to prevent a fall in the blood glucose concentration. When the blood glucose was constantly maintained at the same concentration as during the baseline period, another timed urine specimen was obtained; in patient No. 7 it was possible to obtain a further urine specimen. In the only female patient (No. 6) catheter specimens of urine were obtained.

\section{Results}

These are shown in detail in Table 1. Figure 1 illustrates an individual study (in this case venous blood sugar was also measured). Table 2 compares the 
rate of glucose excretion before and after insulin for each patient and the non-diabetic subject, the results being expressed as milligrams of glucose excreted per minute and also as milligrams of glucose per milligram of urinary creatinine. These results are shown diagramatically in Figure 2; because of the wide variation in the rate of glucose excretion the control period is corrected to 100 and the excretion during the experimental period expressed as a percentage of this.

In all the diabetics the amount of glucose excreted was reduced by insulin, though in only five of them by more than $50 \%$ (mean reduction being $43 \%$ ). Statisti-

Table 2. Comparison of glucose excretion before and during insulin infusion

Patient No. 8 is a non-diabetic control. The blood glucose is expressed as a mean for each period of urine collection

\begin{tabular}{|c|c|c|c|c|c|c|}
\hline & \multicolumn{4}{|c|}{ Glucose Excretion } & \multicolumn{2}{|c|}{ Blood Glucose } \\
\hline & $\mathrm{mg} / \mathrm{min}$ & $\begin{array}{l}\% \text { of } \\
\text { control }\end{array}$ & $\begin{array}{l}\mathrm{mg} / \mathrm{mg} \\
\text { crea- } \\
\text { tinine }\end{array}$ & $\begin{array}{l}\% \\
\text { control }\end{array}$ & mean & $\begin{array}{l}\% \\
\text { control }\end{array}$ \\
\hline $\begin{array}{l}\text { 1A before } \\
\text { after }\end{array}$ & $\begin{array}{c}18.2 \\
7.9\end{array}$ & $43.4 \%$ & - & & $\begin{array}{l}184 \\
177\end{array}$ & $96 \%$ \\
\hline $\begin{array}{l}2 \mathrm{~A} \text { before } \\
\text { after }\end{array}$ & $\begin{array}{l}43.6 \\
19.0\end{array}$ & $43.6 \%$ & $\begin{array}{l}42.3 \\
18.8\end{array}$ & $44.4 \%$ & $\begin{array}{l}209 \\
212\end{array}$ & $103 \%$ \\
\hline $\begin{array}{l}3 \mathrm{~A} \text { before } \\
\text { after }\end{array}$ & $\begin{array}{l}8.8 \\
1.4\end{array}$ & $15.9 \%$ & $\begin{array}{l}2.72 \\
1.17\end{array}$ & $43 \%$ & $\begin{array}{l}132 \\
137\end{array}$ & $104 \%$ \\
\hline $\begin{array}{l}4 \mathrm{~B} \text { before } \\
\text { after }\end{array}$ & $\begin{array}{l}0.77 \\
0.24\end{array}$ & $31.2 \%$ & $\begin{array}{l}0.46 \\
0.24\end{array}$ & $52.2 \%$ & $\begin{array}{l}140 \\
144\end{array}$ & $103 \%$ \\
\hline $\begin{array}{l}5 \mathrm{~B} \text { before } \\
\text { after }\end{array}$ & $\begin{array}{l}181.5 \\
115.4\end{array}$ & $63.6 \%$ & $\begin{array}{l}66.2 \\
63.75\end{array}$ & $96.3 \%$ & $\begin{array}{l}266 \\
270\end{array}$ & $101.5 \%$ \\
\hline $\begin{array}{c}6 \mathrm{~B} \text { before (mean of } 3 \text { ) } \\
\text { after (mean of } 5 \text { ) }\end{array}$ & $\begin{array}{l}31.3 \\
27.4\end{array}$ & $87.5 \%$ & $\begin{array}{l}45.0 \\
40.7\end{array}$ & $90.5 \%$ & $\begin{array}{l}242 \\
244\end{array}$ & $100.8 \%$ \\
\hline $\begin{array}{l}7 \mathrm{~A} \text { before } \\
\text { after (mean of } 2 \text { ) }\end{array}$ & $\begin{array}{l}1.34 \\
0.18 \%\end{array}$ & $\begin{array}{c}13.4 \% \\
(0.01>p>0.001)\end{array}$ & $\begin{array}{l}1.08 \\
0.15\end{array}$ & $\begin{array}{c}13.9 \% \\
(0.02>p>0.01)\end{array}$ & $\begin{array}{l}149 \\
159\end{array}$ & $106.8 \%$ \\
\hline $\begin{array}{l}\text { 8A before (Control) } \\
\text { after }\end{array}$ & $\begin{array}{l}0.16 \\
0.14\end{array}$ & $87.5 \%$ & $\begin{array}{l}0.11 \\
0.105\end{array}$ & 96 & $\begin{array}{l}84 \\
84\end{array}$ & $100 \%$ \\
\hline
\end{tabular}

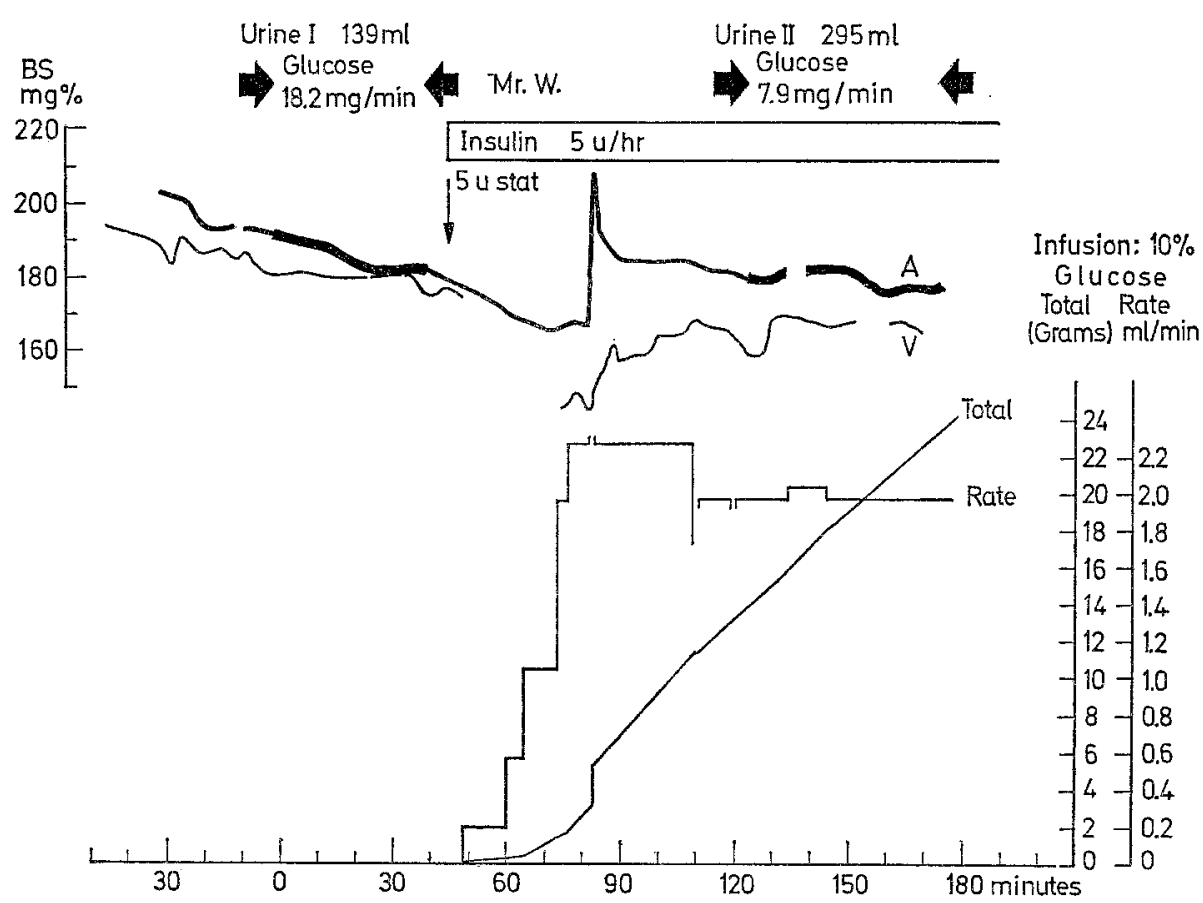

Fig. 1. Details of experiment in Patient 1. Upper portion shows the arterial (A) and venous (V) blood sugars (scale on left) with timing of urine collection and insulin infusion above. Lower portion shows rate of infusion of glucose and total amount given (scales on right). Rapid rise in blood sugar at $83 \mathrm{~min}$ followed injection of $2 \mathrm{~g}$ glucose intravenously 
cal analysis (Students " $t$ " test) of the percentage change shows it to be significant $(0.02>p>0.01$ when the results are corrected for creatinine excretion, and $0.01>p>0.001$ when the results are expressed as milligrams of glucose excreted per minute). It should be noted, however, that the data are not normally distributed. There was no detectable effect in the one normal subject studied.

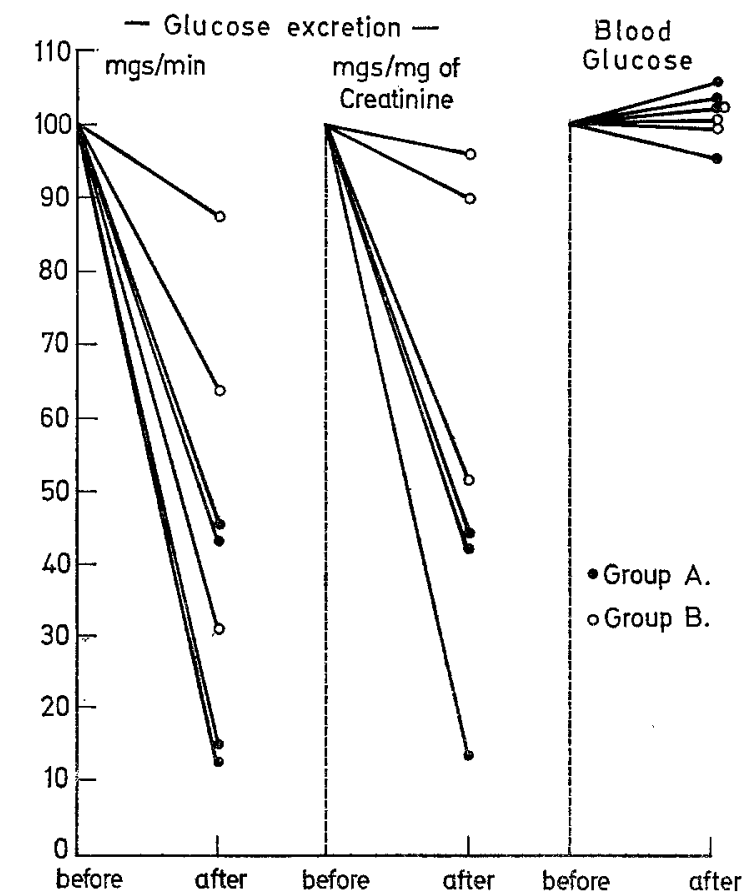

Fig. 2. Results in Table 2 shown diagramatically. Group A 'high dose'. Group B 'low dose'

\section{Discussion}

The aim of the experiment was to demonstrate any effect insulin might have on the renal handling of glucose, and the procedure adopted allowed this to be studied independently of changes in blood glucose concentration. The use of continuous arterial blood glucose monitoring enabled the blood glucose concentration to be maintained at a steady level, by the infusion of intravenous glucose, during the periods that the urine samples were being collected. It will be seen from Figure 1 that $10 \%$ dextrose had to be infused at a rate of approximately $2 \mathrm{ml} / \mathrm{min}$ to overcome the hypoglycaemic effect of 0.1 units of insulin per kilogram body weight per hour. This, incidentally, is a better measure of insulin sensitivity than the tests usually employed, and this technique may be found useful in other investigations.

Although it would have been desirable to have more than one baseline urine collection, the length of the experiment usually precluded this. No control experiment was performed without insulin. However, the results obtained in subject No. 8 (a non-diabetic whose results have not been included in the statistical analysis) and patient No. 5 (a previously treated diabetic who had been given a small dose of insulin subcutaneously six hours before the investigation) suggest that the experimental procedure per se does not lead to a diminution of glycosuria.

To avoid any errors due to incomplete bladder emptying or small changes in glomerular filtration rate, urinary glucose excretion was related to the creatinine excretion in most of the experiments. In the two cases when the glomerular filtration rate was measured, it remained unchanged throughout the experimental procedure.

The urinary flow rate during the control period was frequently smaller than during the experimental period. Glucose excretion was diminished following insulin even in those studies where this initial antidiuresis was absent (i.e. patients 3 and 4). Theoretically, a low rate might be expected to diminish glycosuria, an effect opposite to that actually found, and it can be concluded that the differing flow rates do not affect the interpretation of the results.

The smaller dose of insulin (given to patients in Group B) produced a lesser effect on glucose excretion, and it is possible that this effect is dose dependent. In all the diabetics the glycosuria diminished after insulin had been given even though the blood sugar was unchanged or slightly elevated (in case No. 1 the fall in blood sugar of $7 \mathrm{mg} \%$ was insignificant, and in itself insufficient to account for the diminution in glycosuria). Clearly insulin does not increase glycosuria; on the contrary, these results show that insulin significantly diminishes it independent of changes in blood glucose.

The investigation gives no information as to how this effect is mediated. The kidney is known to be involved in gluconeogenesis [9], and it is possible that the results obtained could be accounted for by an inhibition of this process by insulin. This would imply that the kidney is capable of secreting glucose into the urine, and there is as yet no evidence in support of this. Alternatively, insulin may act by facilitating the tubular reabsorption of glucose. If this is the case, the tubular reabsorptive capacity would have been increased by about $10 \%$ in this investigation - a figure very similar to that found by Henningsen and Benveniste [6] after giving tolbutamide.

Though insulin may not be of prime importance in producing major changes in renal threshold, its effect should be recognized and may influence, for example, the shape and extent of 'splay' found during measurement of the $\mathrm{Tm}_{\mathrm{G}}$. However, it is clear that insulin can affect the renal handling of glucose independent of changes in blood glucose, and this suggests the need to re-evaluate present theories on the renal tubular reabsorption of glucose.

Acknowledgements. Equipment used in some of these experiments was kindly loaned by Technicon Instrument Co. Ltd. The Departments of Clinical Chemistry at 
St. Thomas' and The Middlesex Hospitals performed the estimation of creatinine. Dr. T.H. Foley estimated the G.F.R. in patient No. 2, and Drs. N.W. Oakley and R.C. Turner were of great assistance in studying some of the others. I am most grateful to them. I should like to thank Professor F.T.G. Prunty and Dr. J.D.N. Nabarro for allowing me to study patients under their care, and especially for much helpful advice and eneouragement.

\section{References}

1. Butterfield, W.J.H., Keen, H., Wichelow, M.J.: Renal Glucose threshhold variation with age. Brit. med. J., 1967 IV 505-507.

2. Dzurik, R., Krajei-Lazary, B., Niederland, T.R.: Glucose metabolism in rat kidney: influence of insulin and adrenaline. J. Physiol. 168, 782-786 (1963).

3. Fine, J.: Glucose content of normal urine. Brit. med. J. 1965 I, 1209-1214.

4. Foley, T.H., Jones, N.F., Clapham, W. $\$$.: Determination of glomerular filtration rate with ${ }^{57} \mathrm{Co} . \mathrm{B}_{12}$ measurement of protein binding. Amer. Heart. J. 73, $838-840$ (1967)

5. Hales, C.N., Greenwood, F.C., Mitchell, F.L. Strauss, W.T.: Blood glucose, plasma insulin and growth hormone concentration of individuals with minor abnormalities of glucose tolerance. Diabetologia, 4, 73-82 (1968).
6. Henningsen, P., Benveniste, D.: Effect of Tolbutamide on renal glucose reabsorption. Diabetes 15, 90-92 (1966).

7. Hill, J.B., Kessler, G.: An automated determination of glucose utilising a glucose-oxidase peroxidase system. J. Lab. clin. Med. 57, 970-980 (1961).

8. Joplin, G.F., Fraser, R., Keeley, K.J.: Prednisoneglycosuria test for pre-diabetes. Lancet, 1961 II, $67-70$.

9. Owen, O.E., Felig, P., Morgan, A.P., Wahren, J., Cahill, G.F., Jr. Liver and kidney metabolism during prolonged starvation. J. clin. Invest. 48, 574-583 (1969).

10. Soler, N.G.: Mechanism of Glycosuria in pregnancy. Diabetologia 6, 66 (1970).

11. Spathis, G.S., Hurst, R.J., Pollard, A.: A simple catheter for continuous intravascular sampling. Lancet $1966 \mathrm{II}, 266-267$.

12. - - Continuous intra-arterial and intra-venous sampling using a simple new catheter; and its application to blood glucose monitoring in the assessment of endocrine disease. Automation in Analytical Chemistry; Technicon Symposia, Vol II, 1966. Page 275280.

Dr. G.S. Spathis

Middlesex Hospital

London W., England 